\title{
Xenophobia in Southern Africa: A Pan-Africanist Perspective for Modern Times
}

\author{
Sechaba Khoapa \\ Howard University Alumni, Washington DC, USA \\ Email: skhoapa@hotmail.com
}

Received 3 March 2016; accepted 18 March 2016; published 23 March 2016

Copyright (C) 2016 by author and OALib.

This work is licensed under the Creative Commons Attribution International License (CC BY). http://creativecommons.org/licenses/by/4.0/

(c) (i) Open Access

\section{Abstract}

Xenophobia is historically and in modern times a very systemic political, social and economic manifestation of imperialism. Although successful gains have been achieved, a Pan-Africanist effort to work collectively faces several challenges in the Southern African region. This chapter attempts to pry apart the shell of xenophobia in Southern Africa by examining 1) the Pan-Africanist role of the Southern African Development Community (SADC), 2) understanding the economic, social, and political conditions rooted in xenophobia among SADC countries, 3) xenophobia in South Africa (2008 and 2015), and 4) xenophobia and its implications for future efforts of Pan-Africanism. It is imperative to pinpoint the root agendas and not be consumed by the outward expressions of xenophobia as depicted by media and propaganda. Pan-Africanism is in higher need in modern times than ever before in the past. The challenges seem enormous due to concerns created by modernization and the increasing poverty gaps, clouding the efforts of Pan-Africanism. It's contended that with appropriate understanding and application, the challenges will not out-weigh the gains.

\section{Keywords}

Poverty and Inequality, Economics, Policy Development, South Africa, Pan-Africanism, Social Identity Theory

Subject Areas: Economics, History, Politics, Sociology

\section{Introduction}

We must unite for economic viability, first of all, and then to recover our mineral wealth in Southern Africa, so that our vast resources and capacity for development will bring prosperity for us and additional benefits for the rest of the world. That is why I have written elsewhere that the emancipation of Africa could be the emancipation of Man [1]. 
Kwame Nkrumah spoke profoundly of the idea of true African liberation. He also spoke to the fundamental obstacles that would obstruct the course of that liberation in his post-modern ideology of Neo-colonialism. Before we can dissect the ideological tree, we must have a firm understanding and foundation of its roots.

Best described in Ali Mazuri's pinnacle works explaining the Triple Heritage [2] of African people, this eminently coincides with the subsequent expressions of modern xenophobia. These subsequent expressions are deeply rooted in the ideology of neo-colonialism that must not be ignored. What we observe asxenophobia, historically and now in modern times is very systemic and needs to be examined from a very long political, economic and social telescopic lens.

Let us begin briefly with the globalized displacement of African people that stems from Mazrui's Triple Heritage account of this. To paraphrase, the displacement stems from a historical evolution of indigenousness tradition, colonialism, and modern religion. Now what does that mean? Simply, it means that although successful gains have been achieved, Pan-Africanist efforts to unite African people have faced several challenges in Africa and the diaspora. This dialogue would not even be applicable without reflecting on the Pan-Africanist strides of the Honorable Marcus Mosiah Garvey. This reflection in part stems from a review of Robert Trent Vinson's book, The Americans Are Coming! Dreams of African American Liberation in Segregationist South Africa [3].

Vinson describes an experience whether personal or metaphorical, but more so intellectual between the United States and the Republic of South Africa (AZANIA) during and post-Apartheid. This work from fellow Howard University history alumbreaks down the psychological history of the African Diaspora during the epic years of white supremacy. These epic global years were between 1936 to 1946 that followed the military industrial complex of the 50's and cold war, redefining geo-politics.

In South Africa this would reflect the years before, between and after WWII, as Apartheid as a system collectively began in 1948 with the newly elected National Party's alliance with NATO to govern that region of Africa. This is symbolic politically, because this resulted in a massive dislocation, urbanization and political program in both the United States and South Africa. Keep in mind in 1935, FDR signed the Social Security Act. This was a part of his New Deal to save America during the Great Depression, similar to D.F. Milan's reconstructive policies for Afrikaner refortification after the war, stemming from discrepancies of past military Anglo-Boer relations. The causality was the African who as a result became itemized, and like America became an industry or should we say commodity. I disagree with what Garvey spoke to as post-colonial governance only on definition, but not in concept. His usage of post-colonial did not derail from self-reliance.

The disagreement is that post-colonial implies an end to colonialism where as colonialism in itself is transcendental. Disregarding semantics, Garvey led the largest black political movement in world history, and his movement of Africa for the Africans was a primary mission of African socio-economic and political independence. This also meant an African cultural and traditional independence of religion, education and institutions, with an explicit African-centered worldview linking all of Africa and the Diaspora as a global people.

Marcus Garvey was important because he bridged the gaps left after the late 1890's to the Pan-African movements led by Edward Blyden, Henry Sylvester Williams, and the anti-colonial Pan-Africanist movements of future African leaders like Kwame Nkrumah, Julius Nyerere, Ahmed Sékou Touré, Jomo Kenyatta and Robert Sobukwe, all of whom were influenced by Garvey.

Nkrumah ushered in the term of neo-colonialism to describe the present conditions of African people, and xenophobia in Africa is a current condition created by past symptoms of colonialism. The Southern African region is of no exception due to the residual effects of colonialism, but more importantly the preeminent effects of neocolonialism in modern times.

There needs to be an attempt to pry apart the shell of xenophobia in Southern Africa by understanding the Pan-Africanist role of the Southern African Development Community (SADC). This understanding will explain the economic, social, and political conditions rooted in xenophobia among SADC countries; and subsequently explain the xenophobia attacks in South Africa in 2008 and 2015. Xenophobia and its implications are being confronted by the historic and future efforts of Pan-Africanism.

In order to gain a comprehensive understanding of what historically is a very recent occurrence, it is imperative to pinpoint the root agendas and not be consumed by the outward expressions of xenophobia as depicted by media and propaganda. In modern times there has been a notion that Pan-Africanism is no longer an applicable ideology in certain aspects and in many regards dismissed by many so-called progressives.

Pan-Africanism in modern times seeks to debunk this notion by simply peeling away the systemic layers of xenophobia, and in spite of prevailing conditions within the Southern African region, Pan-Africanism is in high- 
er need in modern times than ever before in the past. Its challenges seem enormous in recent years due to concerns created by modernization such as crippled economies and the increasing poverty gaps, which invariably cloud the efforts of Pan-Africanism. It is contended that with appropriate understanding and application, the challenges will not out-weigh the gains.

The unified efforts of Africa were gravely interrupted by colonialism and slavery; two aspects of capitalism which account for the greatest holocaust in human history. That holocaust seized over 300 million of Africa's young and strong while killing 100 million in the process of the trans-Atlantic slave trade, a barter system of capitalism between England, Spain and Portugal. This barter system between these countries would extend as an exploitive and competitive race in to Africa for land and natural resources, encouraging other nations such as France, Belgium and Germany to join These other nations are key to mention because key Southern African states would inevitably be predominantly colonized by them, changing the course of inter-state relations for decades to come.

We discover that the root causes of xenophobia in Southern Africa are residual expressions of exploitive capitalism and neo-colonialism. Early Pan-Africanists like Nkrumah fore saw these challenges and at least his vision would inspire the Pan-African ideals created by the Southern African Development Community.

\section{The Pan-Africanist Role of the Southern African Development Community SADC}

The Southern African Development Community (SADC) was established in 1992 preceded by the Southern African Development Coordination Conference (SADCC), is a Regional Economic Community consisting of 15 member states that are committed to building better diplomatic relationships through conflict resolution, promote economic growth, and making collaborative efforts to alleviate poverty within Southern Africa Currently, SADC consists of the following member states; Angola, Botswana, Democratic Republic of Congo, Lesotho, Madagascar, Malawi, Mauritius, Mozambique, Namibia, Seychelles, South Africa, Swaziland, Tanzania, Zambia and Zimbabwe [4].

The SADC Common Agenda is underpinned by a series of principles and policies, including:

- Promotion of sustainable and equitable economic growth and socio-economic development that ensures poverty alleviation with the ultimate objective of its eradication;

- Promotion of common political values, systems, and other shared values, which are transmitted through institutions that are democratic, legitimate and effective; and

- Promotion, consolidation and maintenance of democracy, peace and security [4].

The ideology behind the formation SADC as mentioned stems from the SADCC of 1980, although the conference in itself by 1979 into 1980 began as a series of conversations between Angola, Botswana, Lesotho, Mozambique, Tanzania, Zambia and Zimbabwe, formerly known as the Frontline States. As an organization, these states diplomatically represented the regional advocacy for the end of Apartheid in South Africa. Apartheid was not only seen as a human rights issue, but also as a representation of imperialism, neo-colonialism and continued economic oppression.

It is pivotal to understand that with Apartheid South Africa being the political and economic power of the region, it was mutually important for the Frontline States to gain greater economic independence from South Africa which would allow for cooperative opportunities to introduce program initiatives that would benefit the region as a whole. Coincidently, the priority of the initial meeting in Gaborone, Botswana, which later became its head quarters, was for foreign ministers of member states to propose collaborative ideas for future economic development.

The outcome of the meeting in Botswana produced a memorandum outlining a clear agenda for cooperative economic development. As South Africa was outlined in the SADCC objective, research shows that the 1980 signing of this agreement in Lusaka was in part based on that being the headquarters of the then banned African National Congress (ANC). This was later officially called the Southern African Towards Economic Liberation Declaration or Lusaka Declaration, incorporating Malawi and Swaziland becoming a nine member state agreement.

The role of SADC needs to have been seen as a collective intervention to economic neo-colonialism at that time; however the by-product of economic repression remains systemic in modern times. Although Africa's economic development has fundamentally been trying to operate internally, the root cause of the economic repression has been external. 
Many Pan-Africanists in modern times have coined this economic repression as the "new form of slavery". Post African independence, the residual effects of colonial withdrawal left African states indirectly dependent to their former colonizers, but in the spirit of self-sufficiency these states sought propriety from foreign creditor banks and governments in the form of loans. The subsequent debt accumulated had been mounting as early as the mid-1960's and had reached surmountable heights by the 1970's. This was a very critical era in Southern Africa due to the Cold-War and the implications of a Soviet influence within the region. Combined with South Africa's Apartheid government's involvement in regional wars, the instability of the region gave greater justification for higher interest rates in loan repayments.

The greater difficulty facing the repayment of these loans was that they had to be repaid in foreign currency, the cost of global inflation, domestic public finance without viable means of serious production, tariffs and currency exchange rates have rendered debt alleviation nearly impossible. The International Monetary Fund (IMF) and the World Bank would later introduce Structural Adjustment that seemed ideal for African states to be offered lower interest rates on pre-existing loans, or new loans all together to developing economies [5]. However, structural adjustment in the true fashion of neo-colonialism came with stipulations that imposed conditions for African governments to implement public policies that would discourage nationalization of big business, resources, goods and services.

Governments as we observe in modern times, such as in the case of post-Apartheid South Africa enacted policies promoting increased deregulation and privatization under the cloak of a Free Market Economy are examples of IMF and World Bank stipulations for economic aid. Subsequently, these policies would account for decreased spending in critical sector areas from education to health care. These are sector areas that are at the backbone of any self-sufficient society. Without a highly educated and healthy population, that society and inevitably state is habitually dependent on some form of foreign investment at the neglect of its citizens.

\section{The Socio-Economic and Political Conditions Rooted in Xenophobia among SADC States}

This has to be explained as phenomena. This is a system of events or occurrences that transpire over a given time. I speak of Causality that reflects the direct or indirect impacts of state legislative implementation on poverty "how" and why. The phenomena of poverty and inequality have a direct relationship to the socio-economic and political context of it [6].

In this context, external influences that led to the change from SADCC into SADC were much more economically motivated than political. At this juncture we have to consider global economics. The price of oil, currency value, the manufacturing of raw materials, and the global economic liberalism of a so-called free market played a major part in the decision to transform the organization. The change from SADCC to SADC reflected the response of African states conformity to the international trends. The "sink or swim" ideal was at the for-front of economic reforms within SADC. In addition to international political adjustment from the collapse of the Soviet Union ending the Cold War, dismantling of Apartheid, military politics greatly shifted to that of economic security. The post-colonial ideology of economic growth and development became the public policy focus, even on the regional level of new governments as we observed within the reform policies of South Africa's transitional government post-1994 i.e. RDP (Reconstruction and Development Plan) and later the shift to GEAR (Growth, Employment and Redistribution) strategy [7].

In 1996, SADC embarked on a Free Trade protocol within the region that was hoped to be fully entrenched within an eight to 10 year timeframe. World economic demands greatly inhibited this process, particularly as oil was steadily becoming the global currency. The result was African nations having to take a more liberal approach to economics; this meant gains by any and all possible means. Now this is a situation that affected the entire continent, but if we focus on the region, it begins to show the roots of xenophobia. In economics there is commerce which is driven by labor. However, when commerce shifts to technology, it drives the labor force out. This is the same way that the invention of Eli Whitney's cotton gin, pushed out slavery economically. The key word is economically.

The question is what happens to an unutilized labor force? Well let's see how the SADC region from 1996 has declined in the level of human development and increased poverty. This is not to say advancements have not been made, in particular South Africa, but South Africa still has human development, poverty and enormous inequality issues. South Africa represents a Pan-Africanist disappointment and hope at this time. 
What happens closer to 1999, despite vast growth in economic trade within the region, geo-politics still played a large role. The role of "who" controls economic resources. This is evident in the region among members as such the DRC where militias prevail, Namibia and Angola supported armed resolution to conflicts of interest despite SADC's stance of diplomatic conflict resolve. So the divisions are created on a premise of "each his own”. Your problem is no longer my problem mentality.

SADCC before SADC had the ideology of people over money. So when one discusses equality, they also have to discuss money [7]. Global economics greatly shifted the politics of the region, let alone the world. South Africa has yet to be blamed for this, but they are not the reason because individual states have their own responsibilities for the region to have full strength.

I am not sure if SADC has an agenda to help increase economic integration of the full Southern African region without involving other African nations. The purpose is not solely to create human development as a response to global economic liberalism, but hopefully as a means to fight political oppression that exists in the form of neo-colonialism.

\section{Xenophobia in South Africa 2008 and 2015}

This is a particularly difficult section to discuss being firmly rooted in it. As a son of Biko who taught that the humanity of man should never extend past the color or creed of their origin, but be held accountable to their content of action. This is to say that before post-Apartheid South Africa, African immigrants from all countries faced discrimination, abuse, exile and or persecution. Most of these immigrants faced it from within their socalled sovereign independent countries.

To understand the partial but important factor of xenophobia in South Africa, one has to understand the psychology created by the institutionalized racism of that system. In South Africa, not only were you White, Coloured, Indian or African, which all had their own social-economic status and class in the system. Historically we know where the native African in South Africa fell on that pyramid. It's systemic, because the reality of xenophobia is not limited to the regional Africans, but to even black South African expatriates. Imagine the gravity of an African not native to South Africa.

This is where the economic politics of South Africa could not balance itself. The majority population of South Africa under Apartheid was subjugated to an unskilled, under-educated labor force from 1948. With the exception of Namibia, most the southern African countries had reached independence from 1960 to 1980 whereby some collective identity was formed while South Africans were still under civil resistance and struggle. During this time other African states were educating their populations in various fields from medicine, engineering and social anthropology. In this time South Africans were still throwing stones.

Fast-forward post-1994 and the public policy of Black Economic Empowerment (BEE). This policy disenfranchised over 60 percent of the population just in conception alone. The inception became very real when an entire former labor force was deemed un-required. Although a public free education system was initiated, that too was marginalized by the private sectors where by the quality of education was matched to one's economic status. The inevitable reality of any nation that can't fill positions to serve the greater population is that they must recruit from outside. Hence, there has been an influx of skilled immigrants from the Southern African region, looking to invest in South Africa's blossoming economy. Not only that but also fulfilling the employment quotas projected and promised by government legislation.

I paraphrase MsGraca Micael in her 2008 speech of understanding xenophobia after the South African attacks was simple; that poverty and deprivation and the lack of access to basic needs being restricted is dehumanizing at that level of poverty [8].

The cause of this behavior and violence is not unique to South Africa and is similar to any other country. This idea of nationalism is quickly asserted when the social condition and norm is disturbed or threaded. We see it in so many forms even to sports... our team versus you! We will kill you if we lose because you cheated! So incidentally, South African patriotism said that these Kwere Kweres, (foreigners from up north) have come to take over our piece of the country that we fought for! They want our resources, jobs, women, culture, and so on. This would be simple grounds for war of a disenfranchised people don't you think?

Now let us discuss the build ups to this and why. Firstly, xenophobia has to be understood from the socioeconomic status of people in masses. Xenophobia is not an individual effort, it is collective. Poverty and lack of opportunities especially amongst the youth who were sold an idea of equal advancement are unemployed. For 
this sector of the population to watch outsiders arrive, stay and after a few months to a year are financially striving built resentment. I have heard the old African township sayings of why must I buy sugar from a store my Grandfather once owned!??!! Funny or not, this is reality. In the township areas many merchants are indeed from outside, spanning from Mali to Ethiopia, Nigeria, Kenya and Gabon.

Secondly, politics played a huge role, not nationally, but locally. As mentioned above, the township when I say locally. In 2008 local politics had a lot to do with the instigation of xenophobia. In the early 90's before the reformative process and the subsequent release of Nelson Mandela, there was a very high level of immigrates from Somalia, Zimbabwe, DRC and Malawi, not excluding expatriates attempting to return home from exile. The high expectations of the new ANC-led government promised the deliverance of jobs, building housing for the poor, poverty alleviation and some sense of equality regarding social and economic status. This was based on the principles of the ANC Freedom Charter upheld and respected by international interests who fought against Apartheid.

In an attempt to correct the injustices of the Apartheid era, South African voters, namely the poor majority expected the promises made by government to prevail. Keep in mind that so-called foreigners who were emigrating at a high rate were looking for the same opportunities. We have to consider neo-colonialism and war stricken Africa was at a high from Ethiopia, Somali, Sudan and the DRC. The only anti-colonial voice in the Southern Africa region was Zimbabwe, but faced its own domestic and international instabilities. This is around the time when President Mugabe sought capital means from China and other Asian nations for investment. The Chinese were bringing high investment capital with entrepreneurial skills and trade.

This further marginalized the poor because ownership was no longer being based on statesmanship in theory, it became a skills-trade issue and Bantu-Education was architected to do just that. As unemployment increased as a result privatization which was supposed to represent a free market society, it broadened the poverty gap.

\section{Limitations to Government Change in South Africa and Region}

How did the new government redress socio-economic inequalities in 1994 after the political transition? This question is important because the narrative of this conclusion regarding the transition of government legislation and implementation provides a brief explanation of circumstances and constraints that were faced by the ANC government regarding inequality.

After securing governmental control through a Tri-Lateral Agreement (the negotiated agreement of shared power that led to the first all-inclusive election of 1994) it was believed that a reconstructive process would be successful. However, in what has been described as a Class Compromise, the ANC was unable, in a timely fashion to gain popular support from the lower economic class while trying to satisfy the middle and upper-classes [8] [9]. Regardless of race or ethnicity, the initiative became economically based. SES became the central governmental point of focus, which hampered equal distribution in the timeframe proposed earlier within the Tri-Lateral Agreement.

Enthusiasm created by such a monumental transition gave rise to expectations for almost immediate social, political and economic change generated by the RDP. Several decades after democracy, socio-economic disparity is still observed. The RDP ushered in an agenda for reform, and set down an expected timeframe that the new government was to advance. Efforts of the ANC government through socio-economic reform were to appease all South Africans.

Prominent among them was a "sunset clause" providing for a period of compulsory power-sharing in the form of GNU, an offer not to purge the security forces and civil service of "counter-revolutionary" elements, and the willingness to establish (during negotiations) a set of Constitutional Principles that could not be violated by the final Constitution [9].

Economic management to address poverty and inequality would prove to be an uneasy task. This is important to emphasize because the sunset clause is key to understanding the slow pace of transformation towards greater equality. The ANC could draft progressive legislation, but for the first five years it was compelled to use the old civil service to implement those policies [10].

Africans in greater numbers are subject to higher levels of unemployment and poverty than the other racial groups across the general population of South Africa. A prime example in contemporary South Africa is Alexandra Township, Johannesburg. A township settlement developed in 1912 and intended to accommodate 70,000 families, now contains over a million. An estimated 20,000 of those housing units are shacks in the backyards of 
pre-existing housing units, causing maintenance, water, and sewage waste problems because of the unplanned population overload. According to survey data provided by Miriam Altman to the HSRC and quoted in the Dinokeng Scenarios report, "about $40 \%$ of households still live below a poverty line estimated by the Treasury to be about R480 per person per month. Poverty is closely linked to the structural problems of unemployment and the lack of skills [education]; unemployment affects poor households most severely” [11].

How do we close the gap between blacks and whites? When the political initiatives of government represented a multi-racial advancement towards the poor and some middle class sectors, the political transition fell short. Economic policy seemingly got side-tracked and issues, debate and discussions went awry. At the same time as these developments were happening, Gelb states:

Re-constituting group interests via policy debate to establish a new growth model for redistributive change seemed an attainable objective in South Africa in the early 1990s [11].

While South Africans were complaining about unemployment, foreigners are getting employed, especially. Because they are willing to take jobs that South Africans don't want. We see the same phenomena in the United States with Latino/Mexican immigrants. American citizens feel threatened at the same expense of not wanting or willing to perform those tasks. That is why there's been a constant increase of Xenophobia Attacks. As PanAfricanists allow us to reflect on the Fifa World Cup held in Brazil where similar actions took place over the same feelings of disenfranchisement.

I just hope what people can take away from this is the reality of socio-economic oppression and disparity that exist in our societies. We will never condone the horrendous triggers of social injustice and racism that spark violence, riots and protest, but it truly is a global issue, in particular where people of color are concerned... the xenophobia attacks in South Africa are only an example... in fact if you didn't know what you were watching, at first glance you wouldn't know if that was DRC, Baltimore or Johannesburg... how soon we forget... that this was Brazil just 2014. These are different countries, different stimulus, but same outcomes.

It is a failure on the part of Government to meet the needs of its citizens. Voters only become important when it is time to elect new public officials. Xenophobia attacks come as a result of frustration, and without any type of conflict resolution or even discourse, this will continue. Government needs to be aware because if not, we are the dawn of a civil war that will not only impact Azania, but the entire region and world.

\section{Xenophobia and Its Implications for Future Efforts of Pan-Africanism}

If young Africans can embrace the mental concepts of Franz Fanon, Leon Demas and Thabo Mbeki to deal with post-colonial Africa, the African Renaissance could have been imagined. This Pan-Africanist idea is felt among the global African community. The issue has always been intent and collective participation. In Southern Africa this idea of collective participation has been raised. Why has Kenya separated into the COMMON MARKET FOR EASTERN AND SOUTHERN AFRICA (COMESA)? Yet still expects to participate within SADC regions. Kenyan shillings are not being appropriated equally within SADC because that capital is directly linked to the Euro-Dollar and British Pound... this is NEO-COLONIALISM.

When they overthrew Kwame Nkrumah in 1966, it was in part to one of his last publications entitled NeoColonialism describing how to defeat imperialism. If you have not skimmed Nkrumah's Challenge of the Congo, you can't piece together the assassination of Lumumba and the subsequent destabilization of that region. We witnessed the same phenomenon in Burkina Faso that were once the Upper and Lower Volta during the 1980's, so ideologically this is not new when we examine xenophobia as Pan-Africanists in modern times.

Pan-Africanism is an ideology and movement that encourages the solidarity of Africans worldwide [12]. It is based on the belief that unity is vital to economic, social, and political progress and aims to "unify and uplift" people of African descent. The ideology asserts that the fate of all African peoples and countries are intertwined. At its core Pan-Africanism is "a belief that African peoples, both on the continent and in the diaspora, share not merely a common history, but a common destiny" [13].

If South Africans can't identify and relate on a similar basis, national cohesion towards eradicating poverty and inequality becomes more difficult to achieve. Research indicates that one misconception regarding equality practices in post-Apartheid South Africa is that poverty and inequality are synonymous. According to Landman, "In public discourse the two (poverty and inequality) are normally linked and treated as an expression of the same problem. In reality, they are very different. These differences have important public policy consequences.” 
[14] As the Gini coefficient suggests, inequality is measured by the distribution of national income, whereas measuring poverty “depends on a critical assumption: what level of income constitutes the poetry line?” [14]

The manner in which this distinction plays out in governance is that it factors into the public finance of South Africa. Inequality and poverty would benefit from being addressed on separate levels. To implement policies that are intended to bring about equality, BEE being a prime example in this case, has shown that only a small percentage of blacks, who in fact are at certain economic levels, actually benefit from the policy. Citizens who fall below a certain economic level or poverty are in turn further disenfranchised by a policy which in theory was intended to alleviate the economic gap of the South African population.

Although poor people are better off due to targeted spending on the poorest two fifths of the population, and inequality is often a consequence of economic growth, the inequalities that continue to exist threaten social cohesion. Racial inequality also undermines our efforts to build a non-racial society. Above all, poverty seriously inhibits citizenship and participation in civic life [15].

The notion of National development suggests an equality practice that would and should enable all South Africans despite, race, gender or ethnicity, a fair and equal distribution of resources, every citizen should be entitled to government resources purely on the basis of being a South African citizen. With government acts such as BEE that were endorsed by the Department of Labor, based on an emphasis of employment equity would further ensure that employment opportunities would be equitable.

Bottom line this circumstance is related to economics, the reality is that is the majority of the world is struggling due to a FIAT system. FIAT is a Latin phrase that means Let it be so and is the cumulative currencies of the dollar, euro, and pond which essentially control the global economy. Basically all goods and services are exchanged in these currencies on a global level and in order to participate, countries must exchange their currencies to one of these, but the costs associated with this can be enormous. This is how many African states have fallen into un-repayable debt to organizations and banks like the World Bank and IMF. Until Africans can have control of the resources and economy, they will continue to be at a deficit. It is a very big task for any one state to take on without feeling like they are tugging the whole line. When that occurs, such as in the case of South Africa where locals felt that their interests were being squandered by foreigners.

The irony of the xenophobia attacks is that black South Africans never considered white South Africans as the source of their disenfranchisement. After all white South Africans gave up political power, but never gave up their control of the economy and resources. So in many ways Apartheid may be gone, but white supremacy still prevails. White supremacy is the obstacle but continually ushered in through neo-colonialism. The problem it so difficult to counter because 1 ) white supremacy is so engrained as a doctrine that it has become normality in the psychology of the African, 2) the African psychology because of white supremacy operates from a place of inferiority to the detriment of his own people. This means that in an attempt to impress or satisfy the oppressor, he inflicts ill treatment to his fellow African. Black skin, white mask.

Wherever Europeans have founded colonies of the type we are considering, it can safely be said that their coming was unconsciously expected—even desired—by the future subject peoples [16].

\section{Conclusions}

These were visions that Nkrumah warned Africans about and what Muammar Gaddafi was trying to rectify in the years leading to his assassination. You ask yourself if xenophobia would persist if Africans of that region found solidarity among each other's countries. These were attempts made by true Pan-Africanists, as a solution to neocolonialism and white supremacy, for the solution to white supremacy is not black supremacy, but in fact the solution lies in Pan-Africanism.

We regard it as the sacred duty of every African state to strive ceaselessly and energetically for the creation of a United States of Africa from Cape to Cairo and Madagascar to Morocco [17].

Even Robert Sobukwe shared this vision as a South African, in a country that wore the ugly face of xenophobia and violence in 2008 and 2015. I will state that if Africans whether distant or apart do not band together, the role Pan-Africanism in this global and modern time is finished. The history books do not need to tell us this outcome 20 - 25 years from now. If we pay close attention, we will act in an assertive manner because we see absolutely clearly that pan-Africanism in modern times is required more now than ever. 


\section{References}

[1] Nkrumah, K. (1964) Speech. Revolutionary Path, 182-184.

[2] Mazuri, A. (1986) The Africans, Series.

[3] Vinson, R. (2012) The Americans Are Coming! Dreams of African American Liberation in Segregationist South Africa. Ohio University Press, Athens.

[4] Southern African Development Community (SADC). http://www.sadc.int/about-sadc/overview/history-and-treaty/

[5] http://www.globalissues.org/article/3/structural-adjustment-a-major-cause-of-poverty

[6] Yin, R.K. (2009) Case Study Research: Design and Methods. Sage Publications, California.

[7] Shoeman, M. (2009) From SADCC to SADC and beyond: The Politics of Economic Integration. http://www.alternative-regionalisms.org/wp-content/uploads/2009/07/schoemar_fromsadcctosadc.pdf

[8] Michal, G. (2010) Speech. The Southern Africa Trust in Collaboration with AFS Interculture South Africa Launched a New Southern Africa Cross-Border Youth Exchange Programme Called sayXchange, on Thursday 4 February 2010 in Johannesburg. The Programme Was Conceptualised Following the 2008 Xenophobic Attacks in South Africa.

[9] Villa-Vicencio, C. (2010) South Africa: Did the Mandela Revolution Succeed? Lecture, Georgetown University, December 2010.

[10] Khoapa, S. (2014) A Case Study on Poverty and Inequality in Post-Apartheid South Africa: Examining Government Policy and Practices from 1994 to 2012. Dissertation.

[11] Landman, J.P. (2003) Breaking the Grip of Poverty and Inequality in South Africa 2004-2014. Executive Summary, December 2003, 3.

[12] Gelb, S. (2004) Inequality in South Africa: Nature, Causes and Responses. Forum Paper: African Development and Poverty Reduction: Macro-Micro Linkage, October 2004, 22.

[13] Minkah, M. (2015) PanAfricanism. Rutgers University.

[14] Landman, P. (2003) Breaking the Grip of Poverty and Inequality in South Africa 2004-2014. Executive Summary, December 2003, 3.

[15] The Dinkokeng Scenarios (2009) HSRC Affiliated Publication, 25.

[16] Fanon, F. (2008) Black Skin, White Mask. Grove Press, 79.

[17] Sobukwe, R. (1959) PAC Inaugural Speech. 